\title{
Litterfall production and associated carbon and nitrogen flux along exclosure chronosequence at Kewet district, central lowland of Ethiopia
}

\author{
Fikrey Tesfay ${ }^{1,2^{*}} \mathbb{D}$, Kibebew Kibret $^{1} \mathbb{0}$, Aster Gebrekirstos ${ }^{3}$ and Kiros Meles Hadgu ${ }^{4}$
}

\begin{abstract}
Background: Litterfall input and associated nutrient flux are critically important in the restoration of soil in degraded landscapes through exclosures. This study was conducted to evaluate the effects of exclosure on seasonal litterfall production and nutrient content, and estimate annual $\mathrm{C}$ and $\mathrm{N}$ inputs to the soil in an age sequence at Kewet district, central lowland of Ethiopia. Leaf litterfall production was recorded by a $0.25 \mathrm{~m}^{2}$ litter trap from a systematically laid line transects from 5, 15, and 20 years old exclosures and adjacent grazing land.

Results: Leaf litterfall input in the exclosures ranged from $37 \mathrm{~g} \mathrm{~m}^{-2}$ in January (at the old exclosure) to $7.33 \mathrm{~g} \mathrm{~m}^{-2}$ (at the young exclosure), and $3 \mathrm{~g} \mathrm{~m}^{-2}$ in March at the grazing land. Litterfall input showed seasonal variation and peaked in the dry months. Mean monthly leaf litterfall production was significantly $(p<0.05)$ higher $\left(22 \mathrm{~g} \mathrm{~m}^{-2}\right)$ in the old exclosure than the adjacent grazing land $\left(9 \mathrm{~g} \mathrm{~m}^{-2}\right)$. Total annual leaf litterfall ranged from $1073 \mathrm{~kg} \mathrm{ha}^{-1}$ (grazing land) to $2662 \mathrm{~kg} \mathrm{ha}^{-1}$ (old exclosure). There were no significant differences in leaf litterfall nutrients i.e., N, P, K, Ca, and Mg concentrations, except for C. The annual leaf litterfall associated C and N input ranged from 412 (grazing land) to 1025 (old exclosure) and 27 (middle age exclosure) to $68 \mathrm{~kg} \mathrm{ha}^{-1}$ (old exclosure), respectively. The positive change recorded in leaf litterfall production and associated $\mathrm{C}$ and $\mathrm{N}$ return is associated with restoration of vegetation.

Conclusions: Through well-managed area exclosure, leaf litterfall production in the degraded landscapes can reach the level of tropical dry lowland forest in about a decade. Further research on the contribution of dominant tree species in litter production along the age of exclosure is recommended to improve the effectiveness of rehabilitation of degraded lands.
\end{abstract}

Keywords: Decomposition, Dry matter, Leaf litterfall, Nutrients, Restoration, Soil

\section{Background}

Litterfall is a principal biological pathway of organic matter return from plant components to the soil through litter decomposition and subsequent release of nutrients (Rogers 2002; Dawoe et al. 2010; Kim et al. 2010; Demessie et al. 2012). It plays an important role in energy and

\footnotetext{
${ }^{*}$ Correspondence: fikreytesfay@gmail.com

${ }^{1}$ School of Natural Resources Management and Environmental Sciences,

Haramaya University, P.O.Box 138, Dire Dawa, Ethiopia

Full list of author information is available at the end of the article
}

nutrient transfer and maintaining soil fertility (Lindsay and French 2005; Sayer and Tanner 2010). Litterfall leads to the development of the forest floor. Litter accumulated on the soil surface serves as a temporary sink for nutrients (Gautam and Mandal 2018). In the internal biogeochemical cycle of elements of forest ecosystems, litterfall is the third major pool of nutrients (Nordén 1994; Barlow et al. 2007; Oziegbe et al. 2011). Through the decomposition and mineralization process, litter is the primary source of soil organic carbon (SOC) (Lemma et al. 2007; Zhang et al. 2013). It also contributes up to more than 
$70 \%$ of the annual $\mathrm{N}$ input in forest ecosystems (Cotrufo et al. 2005). Soil organic matter is a biochemical continuum ranging from fresh plant detritus to the highly stabilized portions (George et al. 2010). The fraction of the nutrient content in annual litterfall expected to mineralize in one year is called litter nutrient flux (Schulte and Ruhiyat 2013).

Decomposers mineralize and recycle a sizeable amount of $\mathrm{C}$ that is bounded in litterfall to the atmosphere (Osman 2013). Changes in aboveground litter production will have a direct impact on belowground processes (Sayer et al. 2007; Tian et al. 2010; Demessie et al. 2012; Uriarte et al. 2015). Thus, the build-up of SOC and release of nutrients in soils is a dynamic balance between both above (net primary production i.e., in terms of quality and quantity of litterfall) and belowground litter inputs and organic matter outputs (loss through decomposition) in the form of $\mathrm{CO}_{2}$ efflux (Tian et al. 2010; Mehta et al. 2013). Soils may sequester more carbon when the decay rates is slow (Mehta et al. 2013) or inputs of organic matter from plants such as leaf litterfall increase (Chenu et al. 2019).

The amount of annual litterfall varies widely within and between the forest. For instance, the annual litterfall production in the tropical broad-leaved deciduous forest ranges from $5600 \mathrm{~kg} \mathrm{ha}^{-1}$ in dry lowlands forest to $11,700 \mathrm{~kg} \mathrm{ha}^{-1}$ in tropical rain forests (Vogt et al. 1986; Attignon et al. 2004). In Ethiopia, the lowest $\left(310 \mathrm{~kg} \mathrm{ha}^{-1}\right.$ year $^{-1}$ ) litterfall production was reported for the ranging area in the Tigray highlands of the northern part of the country by Descheemaeker et al. (2006). The highest $\left(10,870 \mathrm{~kg} \mathrm{ha}^{-1}\right.$ year $\left.^{-1}\right)$ litterfall production was reported by Lisanework and Michelsen (1994) for a natural forest of Ethiopia. Talemos et al. (2018) also reported a litterfall production of $10,760 \mathrm{~kg} \mathrm{ha}^{-1}$ year $^{-1}$ for a low disturbed moist evergreen montane forest of Southwestern Ethiopia. Despite the very few studies in Ethiopia, these studies exhibited how the annual litterfall production varies within and between forests in the country in response to different factors. Litterfall production and quality depend on several ecological factors (forest type, climate, site quality) (Kim et al. 2010) and stand characteristics (tree size, species, foliar biomass, and age) (Negash and Starr 2013). The quantity and quality of litter production and the decomposition process play an important role in soil fertility in terms of nutrient cycling and formation of soil organic matter (SOM) (Kim et al. 2010; Demessie et al. 2012). In rehabilitating ecosystem from land degradation, the accumulation of organic matter is strongly determined by the succession stages of forest restoration, litter quality, mediated through changing species composition, and microclimate development (Descheemaeker et al. 2006).
In a global context, recently area exclosure is recognized as an effective practice in the rehabilitation of severely degraded lands (Descheemaeker et al. 2006; Mekuria et al. 2007; Özcan et al. 2013; Tang et al. 2016; Zhao et al. 2017; Teketay et al. 2018; Hu et al. 2019). On area exclosures, litter production and organic matter accumulation are parts of vegetation restoration for environmental rehabilitation, which are important processes in nutrient cycling (such as $\mathrm{C}$ and $\mathrm{N}$ ) in terrestrial ecosystems (Descheemaeker et al. 2006) and can change soil nutrients, particularly, C and $\mathrm{N}$ status (Kim et al. 2010). Reduced litterfall production can lead to lower pool sizes of SOC (Zhang et al. 2013). Litter accumulation following vegetation restoration on the degraded landscape using exclosure can be considered as the most important source of SOM. In semi-arid regions, the litter of the ground vegetation is seen as an important source of SOM (Shen et al. 2014). Maintenance of natural forest ecosystems is achieved by the circulation of nutrients through the litterfall and decomposition (Mehta et al. 2013). Litter accumulation and subsequently total SOC can increase with increasing restoration age (Descheemaeker et al. 2006; George et al. 2010). In Tigray, northern Ethiopia, the establishment of exclosure has shown an exponential increase in litterfall production and subsequent improvement in soil fertility (Descheemaeker et al. 2006).

Litterfall production has been widely used by terrestrial ecologists as a good indicator and measure of biomass productivity in forest ecosystems (Tam et al. 1998; Celentano et al. 2011; Tonin et al. 2017). Empirical evidence on annual litterfall production and associated nutrient return is necessary for determining the potential of exclosures to the build-up of SOM in the process of rehabilitation of degraded landscapes (Rai et al. 2016). Yet, there is a limited understanding of litterfall production in area exclosures. In Ethiopia, except in a much-localized area (Descheemaeker et al. 2006), data and literature on the impact of area exclosure on biomass production rate and associated nutrients flux are not well documented. Most previous studies on litterfall production in the country focused on natural and plantation forest (Lisanework and Michelsen 1994; Lemma et al. 2007; Demessie et al. 2012; Talemos et al. 2018) and coffee Agroforestry systems (Negash and Starr 2013). Less attention has been given to litterfall production studies in area exclosures.

Thus, investigating litterfall production and associated $\mathrm{C}$ and $\mathrm{N}$ on area exclosures can play a critical role. In particular, determination of annual leaf litterfall associated $\mathrm{C}$ and $\mathrm{N}$ on area exclosure is fundamental in understanding terrestrial $\mathrm{C}$ and $\mathrm{N}$ cycling and enhancing sequestration of atmospheric $\mathrm{CO}_{2}$ through exclosure. Furthermore, analysis of elemental concentrations in litterfall can also be used as an indicator of limiting nutrients in the 
area exclosures (Oziegbe et al. 2011). More especially, it is important to see the seasonal leaf litterfall dynamics along exclosure chronosequence to verify the effectiveness of area exclosures in the rehabilitation of degraded lands and to improve their management for better ecosystem services. Therefore, this study was conducted to evaluate the effects of area exclosure ages on seasonal litterfall production and litterfall nutrient content and to estimate annual $\mathrm{C}$ and $\mathrm{N}$ inputs to the soil via leaf litterfall.

\section{Materials and methods}

\section{Site description}

The study was carried out in Kewet district, covering an area of $746 \mathrm{~km}^{2}$ and is located in North Shewa Zone of the Amhara National Regional State, Ethiopia (Fig. 1).

Kewet district is located at $213 \mathrm{~km}$ northeast of Addis Ababa at the foot of the western escarpment of the Ethiopian highlands within the coordinates of $9^{\circ} 49^{\prime}$ and $10^{\circ} 11^{\prime}$ latitude North and $39^{\circ} 45^{\prime}$ to $40^{\circ} 6^{\prime}$ longitude East. The district stretches from 1062 to 3148 meters above sea level ( $\mathrm{m}$ a.s.l). Of the total landscape of the district over 69 and $24 \%$ is laid below 1500 and $2300 \mathrm{~m}$ a.s.l, respectively. The area is characterized by a dry kola (dry lowland) climate
(Hurni 1998) with an average annual rainfall of $916 \mathrm{~mm}$ and an annual mean minimum and maximum temperature of 16 and $31{ }^{\circ} \mathrm{C}$, respectively. The higher potential evapotranspiration than precipitation during most periods of the year indicates the occurrence of dry agro-climate (Hartmann 2016) and moisture deficit in the study area (Fig. 2).

The district is situated at Robit marginal graben which is widely covered by transitional and sub-alkaline basalt with minor rhyolite and trachyte eruptive developed from early Tertiary age basalt rock (Tefera et al. 1996). Numerous rhyolite hills occur along the margin of the Robit graben (small rifts) (Williams 2016). All alluvial and colluvial deposits that occur in the valley are derived from these rocks. Eutric Cambisols and Pellic Vertisols are the dominant soil groups in the alluvial fan area of the district, while the lower Piedmont areas are dominantly covered by Calcaric Gleysols and Calcic Cambisols. Over 41 and $26 \%$ of the district land is covered by cultivating land and forest and shrubland, respectively. Maize (Zea mays), Sorghum (Sorghum bicolor (L.) Moench) and Teff (Eragrostis tef) are commonly produced in the district (FAO 2010). Annually, about $12 \mathrm{~km}^{2}$ of the cultivated land is irrigated and produce horticultural crops such as

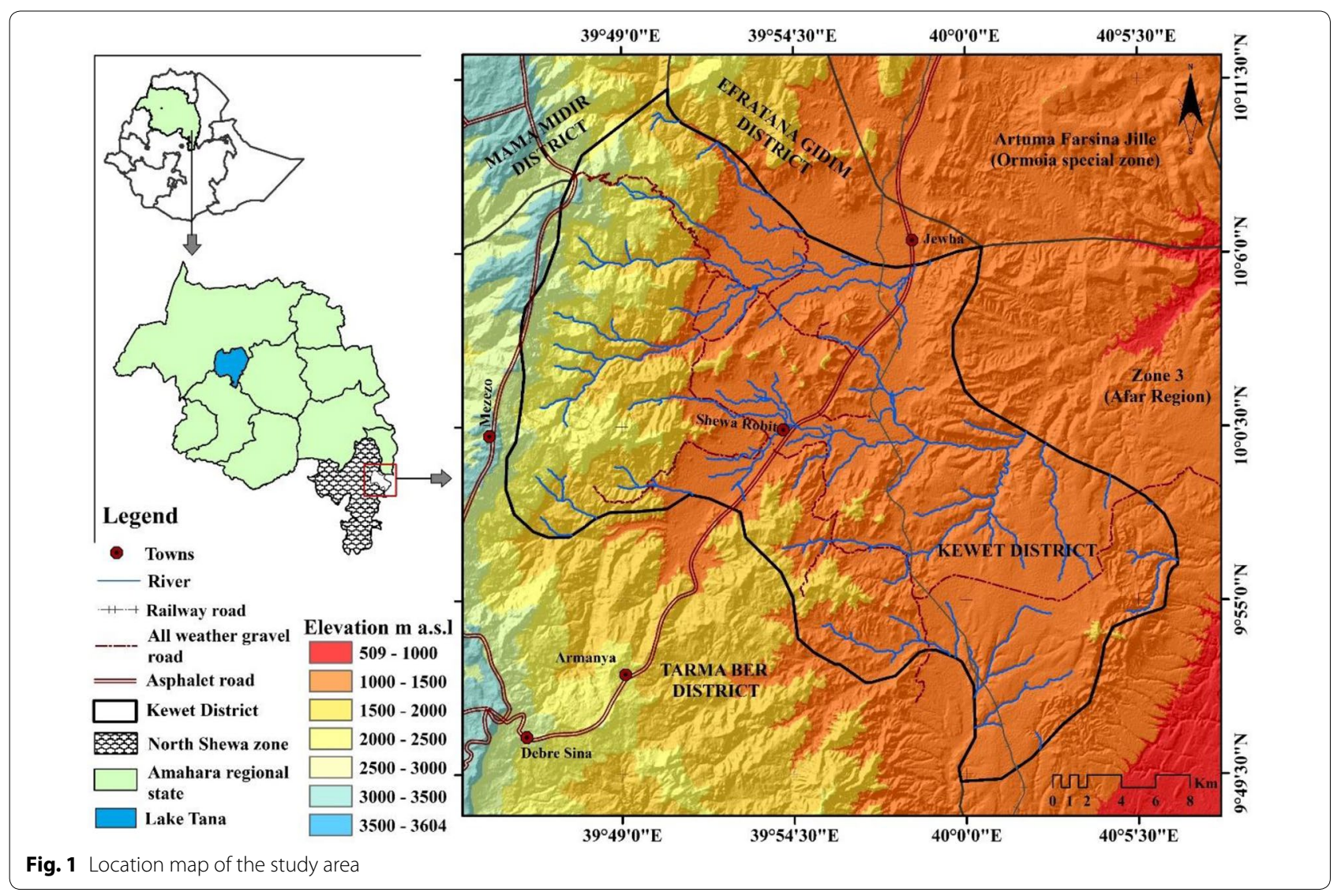




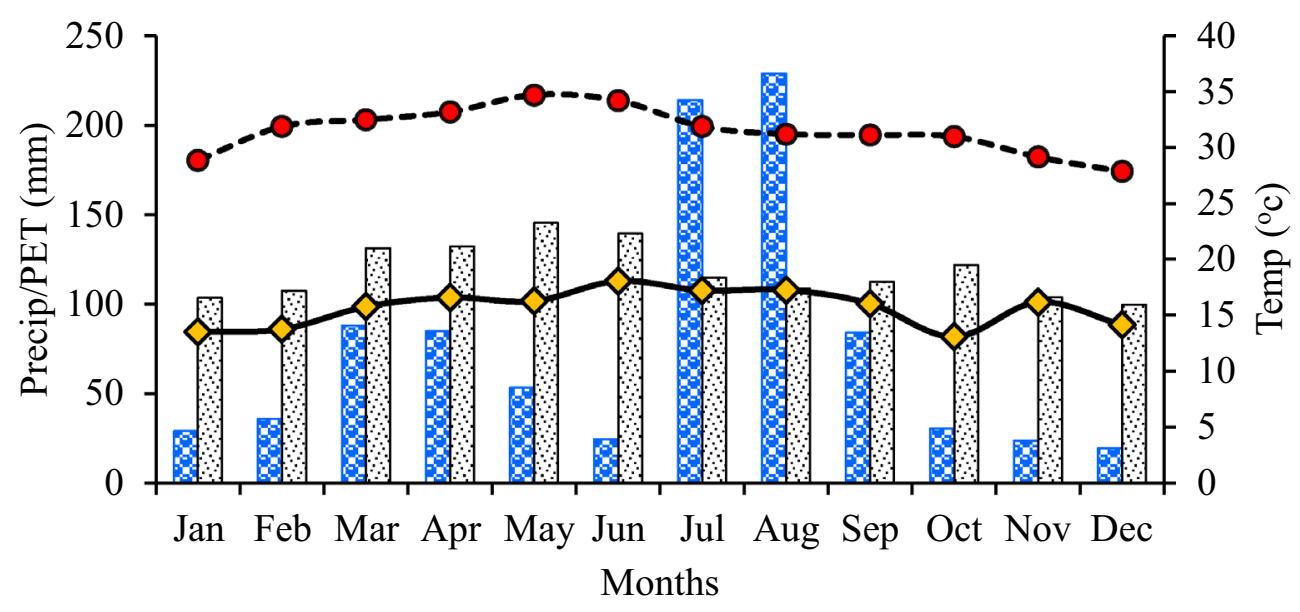

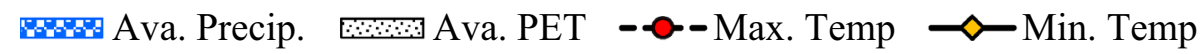

Fig. 2 Monthly average rainfall ( $\mathrm{mm}$ ) and monthly maximum, minimum, and average temperature $\left({ }^{\circ} \mathrm{C}\right.$ ) at Kewet district (2006-2017) (Source: Climate data were obtained from the Ethiopian National Metrology Agency)

Onion (Allium cepa L.) and fruit trees like Mango (Mangifera indica) and citrus (Citrus sinensis L.).

\section{Litterfall sampling and collection methods}

For this study, three exclosures which are about five (Karajejeba site 2), 15 (Karajejeba site 1), and 20 (Merye) years old and one open grazing land adjacent to the respective exclosures were selected. The three exclosures were open degraded grazing lands before they were excluded from free intervention of humans and domestic animals. The exclosures are dominated by woody species such as Acacia brevispica, Acacia nilotica, Acacia tortilis, Acacia senegal, Dichrostachys cinerea, and Grewia villosa.

Within each age exclosure and its adjacent grazing land, three parallel line transects perpendicular to contour lines were laid. At regular distances (upper, middle, and lower landscape positions) along each transect line, a representative sampling point was marked (Vitousek 1984). Three litterfall trap nets at each marked landscape position making a total of nine trap nets per exclosure were randomly placed for this experiment. Accordingly, a total of 36 trap nets were used for litterfall collection. Litterfall samples were collected using a nested $0.25 \mathrm{~m}^{2}$ (Proctor et al. 1983; Buh Rquez et al. 1999; Lindsay and French 2005; Barlow et al. 2007) wooden framed open boxes which have $30 \mathrm{~cm}$ height with $1 \mathrm{~mm}$ nylon screen mesh base. Locally available and cheap wood material which is eucalyptus was used to construct the frame of the trap net (Fig. 3). This was done to minimize the loss of trap nets and make easy the replacement of damaged ones. Each trap net was raised on four wooden stands placed $15 \mathrm{~cm}$ above the floor and treated with preservatives to prevent decay (Dawoe et al. 2010). To minimize blowing out of litterfall due to wind and missing traps, litterfall was collected every 15 days (Proctor et al. 1983). Emptying leaf litterfall trap nets every two weeks also is assumed to minimize the rapid decomposition of leaf litterfall in traps that can lead to substantial underestimation of litterfall (Vitousek 1984).

Litterfall samples were collected for a period of 1 year (Proctor et al. 1983; Ryan and Law 2005) from January 2017 to December 2017. Two consecutive litterfall collections of one nested $0.25 \mathrm{~m}^{2}$ wooden framed open boxes were aggregated into one bag to make one sample per month (Proctor et al. 1983). Missing trap nets were replaced at every sampling event and missing records were substituted by the average of the previous month and the next month of the same location (Descheemaeker et al. 2006). On average, leaf litterfall account from $60 \%$ (Martinez-yrizar and Sarukhan 1990; Lisanework and Michelsen 1994; Rogers 2002; Osman 2013) to 70\% of fine litterfall (Vitousek 1984; Descheemaeker et al. 2006), although there is variation among forests. Thus, in this study, litterfall implies only the aboveground leafy materials.

\section{Litterfall nutrient analysis}

Collected litterfall samples from each trap nets were separated from animal debris, feces, and other non-leaf litter components, and then all samples were weighed after drying them at $65{ }^{\circ} \mathrm{C}$ for $48 \mathrm{~h}$ (until constant weight) (Descheemaeker et al. 2006; Dawoe et al. 2010). Finally, one sub-sample per line transect was prepared from a 


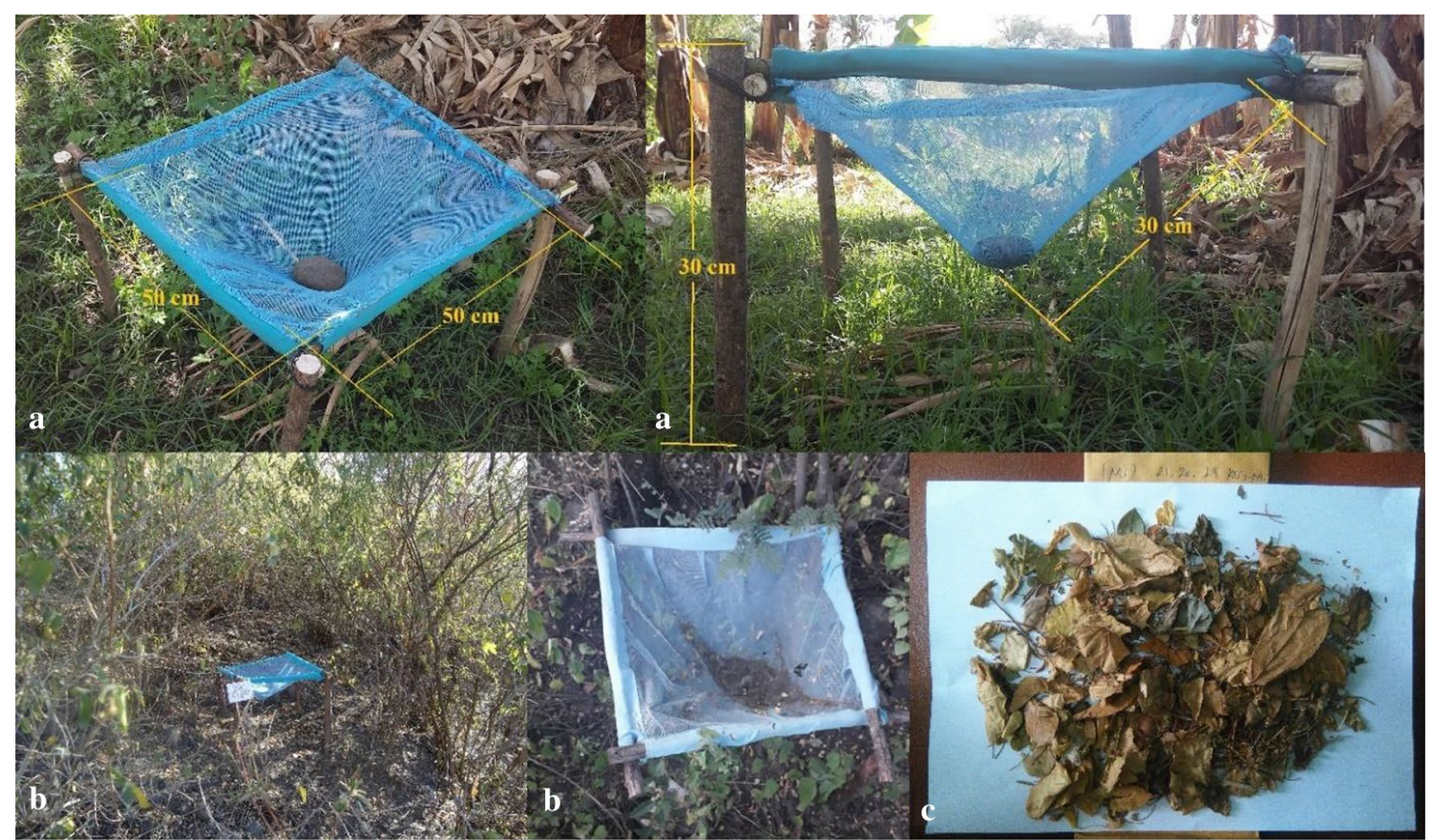

Fig. 3 Image showing the litterfall trap a design, b installed at the field and c composite leaf litterfall sample

composite sample of litterfall that was made by aggregating all month's litterfall collections from the line transect. Three sub-samples for each exclosure and a total of twelve sub-samples were considered for leaf litterfall chemical analysis. Afterward, samples were pulverized to a fine powder and passed through a $0.5 \mathrm{~mm}$ sieve size. Carbon in litterfall was determined after loss-onignition (LOI) by igniting the samples in a muffle furnace at $550{ }^{\circ} \mathrm{C}$ for $2 \mathrm{~h}$ (Anderson and Ingram 1993), and total organic $\mathrm{C}$ was estimated to be $44 \%$ of ash-free dry weight (Negash and Starr 2013). Total N in litterfall was determined using the standard micro-digestion method after the wet digestion of the samples with $\mathrm{H}_{2} \mathrm{SO}_{4}$ (Bremner and Mulvaney 1982). Leaf litterfall concentration of P, $\mathrm{K}, \mathrm{Ca}$, and $\mathrm{Mg}$ was determined after wet digestion of the litterfall dry material with concentrated $\mathrm{HNO}_{3}$ using a spectrophotometer for $\mathrm{P}$, using atomic absorption spectrophotometer for $\mathrm{Ca}$ and $\mathrm{Mg}$ and using a Flame photometer for K (Motsara and Roy 2008).

\section{Determination of annual litterfall production rate and C and $\mathrm{N}$ fluxes}

Monthly mean litterfall dry matter production $\left(\mathrm{g} \mathrm{m}^{-2}\right)$ per each area exclosure age was calculated by dividing the combined litterfall mass of a given sample trap per area of exclosure age (Descheemaeker et al. 2006; Negash and Starr 2013). Annual litterfall $\mathrm{C}$ and $\mathrm{N}\left(\mathrm{kg} \mathrm{ha}^{-1}\right)$ fluxes for each area exclosure age class were calculated by multiplying the annual litterfall production $\left(\mathrm{kg} \mathrm{ha}^{-1}\right)$ by the respective $\mathrm{C}$ and $\mathrm{N}$ contents (\%) and the appropriate unit correction coefficient (Montagnini et al. 1993; Gower and Son 2010; Negash and Starr 2013).

\section{Statistical analysis}

Leaf litterfall dry matter and nutrient concentration data were subjected to one-way ANOVA following the GLM procedure using the SAS 9.2 statistical software. Tukey's Honest Significant Difference (HSD) test was used for mean separation $(p<0.05)$. Pearson correlation coefficient analysis was performed to see whether the mean monthly leaf litterfall production correlated with monthly average rainfall.

\section{Results and discussion Leaf litterfall production}

Leaf litterfall production along all exclosures and adjacent grazing land displayed a strong seasonal variation. It ranged from $37 \mathrm{~g} \mathrm{~m}^{-2}$ in January (old exclosure) to $7.33 \mathrm{~g} \mathrm{~m}^{-2}$ (young exclosure) and $3 \mathrm{~g} \mathrm{~m}^{-2}$ in March (grazing land) (Fig. 4). In all exclosures, relatively higher leaf litterfall input was recorded in the dry months than the wet months. From October to January higher leaf litterfall input was recorded in the young and old exclosures (Fig. 4). Of the total leaf litterfall produced in each exclosure, less than $45 \%$ of the litterfall in the young and 

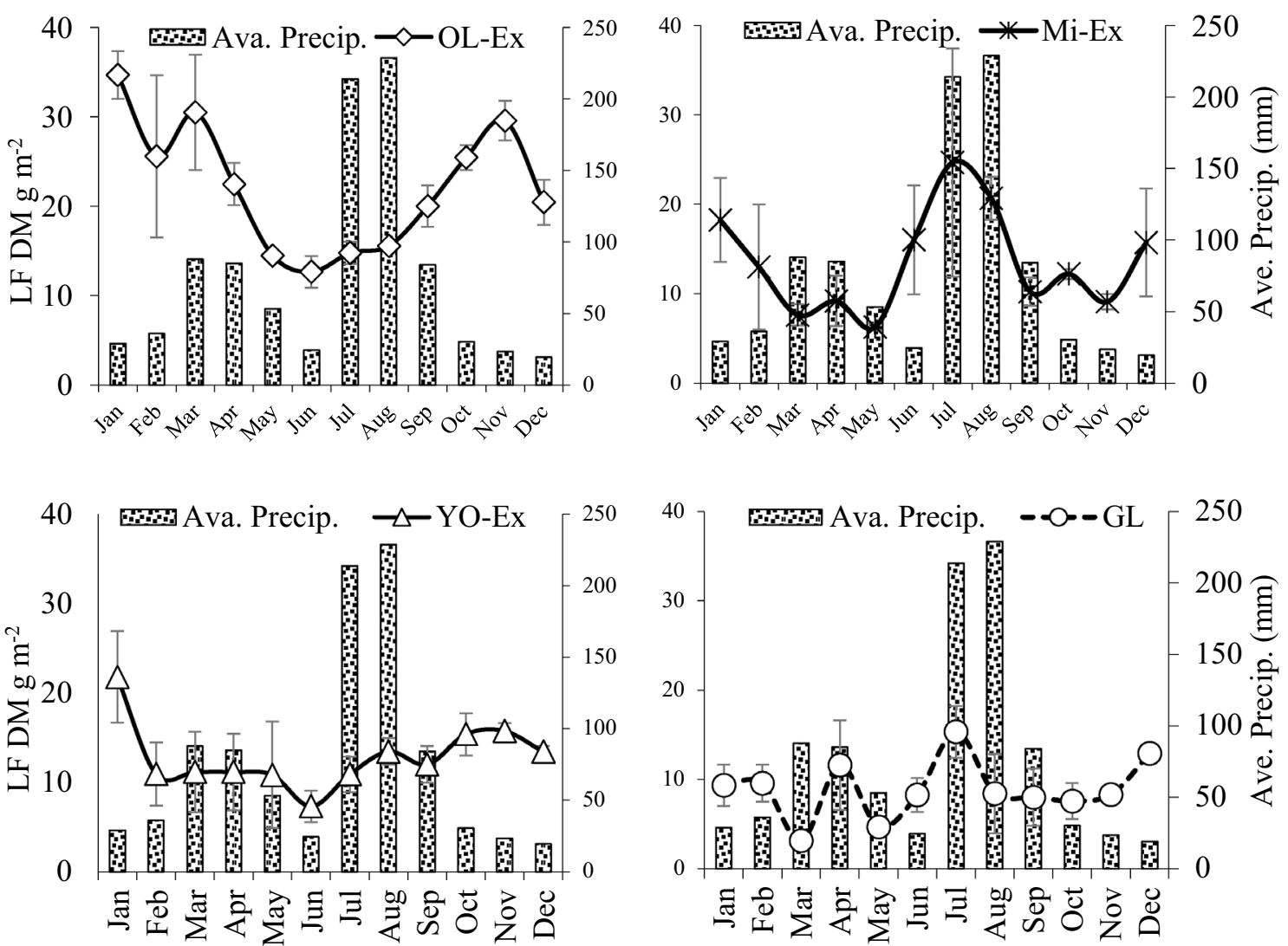

Fig. 4 Leaf litterfall dry matter production at exclosures and grazing land in Kewet district, central dry lowland of Ethiopia. GL Grazing land, YO-EX Young age exclosure, MI-Ex Middle age exclosure, OL-Ex Old age exclosure

old exclosure and less than $48 \%$ in the middle age exclosure and grazing land was recorded in the wet months.

The peak leaf litterfall production was recorded in January at the young $\left(22 \mathrm{~g} \mathrm{~m}^{-2}\right)$ and old $\left(36 \mathrm{~g} \mathrm{~m}^{-2}\right)$ exclosures, while the middle age exclosure $\left(25 \mathrm{~g} \mathrm{~m}^{-2}\right)$ and the adjacent grazing land $\left(15 \mathrm{~g} \mathrm{~m}^{-2}\right)$ produced the highest leaf litterfall in month of July. Lowest leaf litterfall production at the young $\left(7 \mathrm{~g} \mathrm{~m}^{-2}\right)$ and old $\left(13 \mathrm{~g} \mathrm{~m}^{-2}\right)$ exclosures were recorded in June, whereas, the middle age exclosure $\left(6 \mathrm{~g} \mathrm{~m}^{-2}\right)$ and the grazing land $\left(3 \mathrm{~g} \mathrm{~m}^{-2}\right)$ produced the lowest litterfall values in the month of May and March, respectively (Fig. 4). The temporal variation in the peak period of leaf litterfall production in all the exclosures might be attributed to the difference in dominant tree species between the sites, seasons, and stand age.

Several studies have documented that litterfall production in tropical forests is closely related to rainfall seasonality (Becker et al. 2015; Tonin et al. 2017), solar radiation (Paudel et al. 2015; Tonin et al. 2017) and soil moisture content (Martinez-yrizar and Sarukhan 1990; Negash and Starr 2013). Litterfall seasonality in tropical forests depends on plant composition because plant phenological responses to environmental variation vary among species (Paudel et al. 2015). For instance, Rai et al. (2016) observed a significant difference in the amount of leaf litterfall across tree species in tropical dry forests of Vindhyan highland, India. An experiment conducted by Descheemaeker et al. (2006) in Tigray, northern Ethiopia showed that peak leaf litterfall production for deciduous shrubs such as Becium grandiflorum and Salvia schimperi, was in November (dry month) and in January for Acacia saligna tree. Negash and Starr (2013) in the indigenous Agroforestry systems in the southeastern Rift Valley escarpment of Ethiopia have also reported higher leaf litterfall for Erythrina burcie from June to August (wet season) and for Magnifera indica and Persea americana from November to December (drier season). In the semiarid Southern African Savanna Woodland in Bulawayo, Zimbabwe Mlambo and Nyathi (2008) have also recorded much higher litterfall during the dry period (May-September) compared to other months.

Litterfall production investigations in tropical forests by Becker et al. (2015) and Barlow et al. (2007) in secondary Amazon forests, and by Paudel et al. (2015) 
in a tropical montane forest of southwest China, exhibited and evidenced a large peak litterfall during the dry season. Becker et al. (2015) also reported a large peak litterfall input towards the end of the dry season in secondary forest at Mt. Kilimanjaro. The highest peak of litter production was also observed between April and June for natural forest in Gambo District, southern Ethiopia (Demessie et al. 2012). Similarly, Lisanework and Michelsen (1994) reported a higher total litterfall during the drier months in the montane forest of the central highland of Ethiopian. However, investigations of leaf litterfall production in tropical rainforest in southwest Congo by Loumeto (2003) and in secondary Amazon forests by Barlow et al. (2007) showed that monthly leaf litterfall production was negatively correlated with rainfall.

The variation in leaf litterfall input peak period in this study could also be due to the exclosures successional stage. The seasonal peaks of litter accumulation may change with the successional age of the site (Facelli and Pickett 1991). Studies in several exclosures in Ethiopia have shown that the dominance and composition of tree species vary with the age of the exclosure. A similar study by Descheemaeker et al. (2006) reported a variation in the peak of leaf litterfall input between different age of exclosures in Tigray, north Ethiopia. They reported a peak leaf litterfall production period from October to January in adjacent grazing land, from October to February in young and old exclosures and from November to April in matured church forest.

The mean monthly leaf litterfall production of this study showed a significant difference between the age of exclosures and adjacent grazing land (Table 1). Mean monthly leaf litterfall production was significantly $(p<0.001)$ higher $\left(22 \mathrm{~g} \mathrm{~m}^{-2}\right)$ in the old exclosure and lower $\left(9 \mathrm{~g} \mathrm{~m}^{-2}\right)$ in the adjacent grazing land. The total annual leaf litterfall observed in this study ranged from $107.3 \mathrm{~g} \mathrm{~m}^{-2}$ at the grazing land to $266.24 \mathrm{~g} \mathrm{~m}^{-2}$ at the old exclosure (Table 1 ). This indicates that the mean monthly leaf litterfall production increased with an increase in the age of exclosure area. The total leaf litterfall production obtained from the grazing land and exclosures in this study was higher than that reported by Descheemaeker et al. (2006) which is 21 and $24 \mathrm{~g} \mathrm{~m}^{-2}$ in the grazing area and 160 and $231 \mathrm{~g} \mathrm{~m}^{-2}$ in old exclosures in May'ba'ati and Kunale sites in Tigray, northern Ethiopia. The result of this study is comparable with the experiment of naturally regenerated tropical forests (Celentano et al. 2011) in Costa Rica which reported total annual leaf litterfall production of 1230 and $5430 \mathrm{~kg} \mathrm{ha}^{-1}$ for 5 and 9 years old exclosure, respectively. Leaf litterfall in the old exclosure is higher than the leaf litterfall $\left(218 \mathrm{~g} \mathrm{~m}^{-2}\right.$ year $\left.^{-1}\right)$ reported for semi-arid Southern African Savanna
Table 1 Mean (S.E) monthly leaf litterfall dry matter production and its Pearson correlation coefficient with monthly average rainfall at exclosures and grazing land in Kewet district, central dry lowland of Ethiopia

\begin{tabular}{|c|c|c|}
\hline Land use & $\begin{array}{l}\text { Litterfall dry matter } \\
\left(\mathrm{g} \mathrm{m}^{-2}\right)\end{array}$ & $\begin{array}{l}\text { Pearson } \\
\text { correlation } \\
\text { coefficient }(r)\end{array}$ \\
\hline Grazing land & $8.94 \pm 0.83^{c}$ & $0.27^{\mathrm{ns}}$ \\
\hline Young exclosure & $12.84 \pm 0.99^{b c}$ & $-0.19^{\text {ns }}$ \\
\hline Middle exclosure & $13.57 \pm 1.54^{b}$ & $0.56^{\mathrm{ns}}$ \\
\hline Old exclosure & $22.19 \pm 1.45^{\mathrm{a}}$ & $-0.43^{\mathrm{ns}}$ \\
\hline$p$-value & 0.03 & \\
\hline CV \% & 50.53 & \\
\hline
\end{tabular}

Mean \pm S.E. with different letters within a column are significantly different $(p<0.05)$ (Tukey's test HSD)

$\mathrm{CV}$ coefficient of variance

ns Correlation is non-significant at the 0.05 level

Woodland in Bulawayo, Zimbabwe by Mlambo and Nyathi (2008).

However, when compared with the reports of Descheemaeker et al. (2006) for church forest $\left(425 \mathrm{~g} \mathrm{~m}^{-2}\right)$ in Tigray, northern Ethiopia, the annual leaf litterfall production in the old exclosure $\left(266.24 \mathrm{~g} \mathrm{~m}^{-2}\right)$ of this study was very low. The annual leaf litterfall production of this study is was also low when compared with annual leaf litterfall production for lowland humid Ghana Forest $\left(6900 \mathrm{~kg} \mathrm{ha}^{-1}\right)$ (Dawoe et al. 2010) and for secondary Amazon forests $\left(6800 \mathrm{~kg} \mathrm{ha}^{-1}\right)$ of Brazil (Barlow et al. 2007). The low annual leaf litterfall production in this study might be attributed to the difference in stand age and species diversity and density between the exclosures and adjacent grazing land. Annual litterfall production is influenced by several factors i.e., forest stand age, forest type or species composition and density as well as other biophysical factors (Lv et al. 2013; Paudel et al. 2015). Similarly, a study conducted by Tang et al. (2010) in Xishuangbanna, Southwest China, suggests that litterfall production and decomposition processes are influenced strongly by the specific assemblage of coexisting species and their age.

Litterfall production increases with species diversity and the maturity of forest stands. For example, Lisanework and Michelsen (1994) reported a higher leaf litterfall in a matured natural forest than even-aged plantation forests in Menagesha State Forest, highlands of Ethiopia. Demessie et al. (2012) also indicated a higher leaf litterfall in the diversified natural forest than coniferous plantation in Gambo District, southern Ethiopia. Vigorously grown with closed a canopy and less disturbed forests produce higher litterfall. A study in the moist evergreen montane forest of southwestern Ethiopia by Talemos et al. (2018) 
found less litterfall $\left(3280 \mathrm{~kg} \mathrm{ha}^{-1}\right)$ in a highly disturbed forest than low disturbed forests $\left(4540 \mathrm{~kg} \mathrm{ha}^{-1}\right)$.

Exclosure is a passive mechanism of restoration that transforms degraded landscapes to the densely covered landscape. Thus, exclosures will exhibit a spectacular variation in plant species composition, tree density, and canopy closure with increasing age. Despite the low amount of litterfall in all exclosures and adjacent grazing land, this study has shown that leaf litterfall has increased with an increase in the exclosure's age (Table 1). Therefore, this suggests that with increasing age of exclosure, leaf litterfall production in the degraded landscapes could reach the level of leaf litter production in the tropical dry lowland forest.

\section{Nutrients concentration in leaf litterfall}

Statistical analysis showed that leaf litterfall $C$ content significantly $(p<0.05)$ varied between exclosures and adjacent grazing land (Table 2). Leaf litterfall $\mathrm{C}$ was higher $(p<0.05)$ in the young exclosure and it was lower in the adjacent grazing land and middle age exclosure. On the contrary, leaf litterfall $\mathrm{N}$ concentration showed a non-significant $(p>0.05)$ difference between the age of exclosure and adjacent grazing land (Table 2). Even though the difference was not statistically significant, the leaf litterfall $\mathrm{N}$ concentration in the young exclosure was $39 \%$ higher than the grazing land and old exclosure. The nitrogen-rich dominant vegetation species expected to succeed following exclusion might explain this. In a study of leaf litterfall and litter decomposition in Gambo District, southern Ethiopia, Demessie et al. (2012) reported $45 \% \mathrm{C}$ and $1.8 \% \mathrm{~N}$ concentration in leaf litterfall from natural forest. Similarly, in an Acacia species dominated moist evergreen montane forest in southwestern Ethiopia a very low leaf litterfall C from slightly $(25 \%)$ and higher (26\%) disturbed forest was recorded by Seta et al. (2017), though it was higher than the $\mathrm{C}$ recorded in this study. However, they observed higher $\mathrm{N}$ content of leaf litterfall in slightly and highly disturbed forest than this study.
The increased $\mathrm{N}$ content of leaf litterfall in the young age exclosure implies that soil $\mathrm{N}$ beneath this exclosure will be positively affected. A review by Lindsay and French (2005) showed an increased quantity of soil nitrogen due to the higher quality and quicker decomposing Chrysanthemoides monilifera leaves (Lindsay and French 2005).

Carbon to nitrogen ratio $(\mathrm{C}: \mathrm{N})$ of the leaf litterfall ranged from 13:1 in the young exclosure to 19:1 in the middle age exclosure (Table 2). The variation in C:N ration between exclosures and adjacent grazing land might be due to the difference in tree species composition among the age of exclosures. Similarly, Uriarte et al. (2015) found higher $\mathrm{N}$ concentration and lower C:N ratios in pioneer and early successional species than latesuccessional species. Legume species which are important in recycling of nutrient through litter decomposition have a relatively low $\mathrm{C}: \mathrm{N}$ ratio compared to other species (O'connell and Menage 1982). The lower C:N ratio in the old exclosure might increase the $\mathrm{C}$ and nutrient turnover rates in soil and thus accelerates the ecosystem $C$ and nutrient cycling (Becker et al. 2015).

Leaf litterfall nutrients i.e., N, P, K, Ca and Mg concentration were not significantly $(p>0.05)$ different between the age of exclosure and adjacent grazing land (Table 2). Uriarte et al. (2015) reported a similar result in that they found an insignificant difference in leaf litterfall nutrient concentration among disturbance categories for a subtropical wet and montane forest in northeastern Puerto Rico. Except for K, relatively high mean values of nutrients concentration were observed in the young exclosures.

Leaf litterfall nutrients concentration in the young and the adjacent grazing land was in the order of $\mathrm{C}>\mathrm{N}>\mathrm{Ca}>\mathrm{K}>\mathrm{P}>\mathrm{Mg}$. The middle-aged and old exclosures showed the order of $\mathrm{C}>\mathrm{Ca}>\mathrm{N}>\mathrm{K}>\mathrm{P}>\mathrm{Mg}$ and $\mathrm{C}>\mathrm{N}>\mathrm{Ca}>\mathrm{P}>\mathrm{K}>\mathrm{Mg}$, respectively. The order of leaf litterfall concentration at all the sites coincides with the physiological mobility of plant nutrients. Elements with low mobility in plant tissue showed higher concentrations

Table 2 Mean (S.E) values of selected chemical properties of leaf litterfall at exclosures and grazing land in Kewet district, central dry lowland of Ethiopia

\begin{tabular}{|c|c|c|c|c|c|c|c|}
\hline Factors & $\mathrm{C} \%$ & $\mathrm{~N} \%$ & $C: N$ & $P\left(g_{k g}^{-1}\right)$ & $\mathrm{K}\left(\mathrm{g} \mathrm{kg}^{-1}\right)$ & $\mathrm{Ca}\left(\mathrm{g} \mathrm{kg}^{-1}\right)$ & $\mathrm{Mg}\left(\mathrm{g} \mathrm{kg}^{-1}\right)$ \\
\hline$G L$ & $38.14 \pm 0.22^{b}$ & $2.57 \pm 0.67$ & $17.41 \pm 5.02$ & $7.10 \pm 2.25$ & $8.77 \pm 1.23$ & $17.30 \pm 1.53$ & $1.41 \pm 0.22$ \\
\hline YO-EX & $40.21 \pm 0.41^{a}$ & $3.58 \pm 0.87$ & $13.31 \pm 4.30$ & $6.86 \pm 2.22$ & $7.50 \pm 0.46$ & $10.25 \pm 4.01$ & $1.61 \pm 0.35$ \\
\hline MI-Ex & $38.20 \pm 0.70^{b}$ & $2.02 \pm 0.15$ & $19.06 \pm 1.11$ & $5.22 \pm 0.86$ & $8.76 \pm 2.01$ & $21.08 \pm 1.20$ & $1.50 \pm 0.11$ \\
\hline OL-Ex & $38.51 \pm 0.24^{a b}$ & $2.57 \pm 0.67$ & $17.63 \pm 5.18$ & $9.00 \pm 0.44$ & $8.01 \pm 1.00$ & $18.86 \pm 2.31$ & $2.02 \pm 0.02$ \\
\hline$p$-value & 0.03 & 0.44 & 0.80 & 0.49 & 0.88 & 0.07 & 0.27 \\
\hline CV \% & 1.94 & 41.79 & 43.52 & 40.58 & 27.29 & 25.75 & 22.61 \\
\hline
\end{tabular}

Mean \pm S.E. with different letters within a column are significantly different $(p<0.05)$ (Tukey's test HSD)

$C V$ coefficient of variance, GL Grazing land, YO-Ex Young age exclosure, MI-Ex Middle age exclosure, OL-Ex Old age exclosure 
in leaf litterfall. Other experiments from tropical lowland forests observed relatively similar results with this study. In agreement with this finding, Oziegbe et al. (2011) recorded a decreasing leaf litter nutrient concentration in the order of $\mathrm{N}=\mathrm{Ca}>\mathrm{K}>\mathrm{P}$, in the secondary lowland rain forest in, Nigeria. Mlambo and Nyathi (2008) also found a similar leaf litterfall nutrient concentration in semi-arid Southern African Savanna woodland in Bulawayo, Zimbabwe with the order of $\mathrm{C}>\mathrm{Ca}>\mathrm{N}>\mathrm{Mg}>\mathrm{K}>\mathrm{P}$.

Despite the non-significant difference in leaf litter nutrient concentration among the exclosures, the difference in the absolute mean values could be attributed to stand age and difference in species between the sites. Usually, species is one of the dominant factors that determine the concentration of nutrients in litterfall (Osman 2013). Nordén (1994) indicated nutrient concentration differences between tree species. The successional stage (stand age) can also strongly affect aboveground biomass (Osman 2013). Descheemaeker et al. (2006) in Tigray, northern Ethiopia observed high litter nutrient content in early successional forest stages which are characterized by pioneer species. In dry forest ecosystems of southwestern Australia, high levels of leaf litter N, P, and K were obtained in the youngest stand and the concentrations decreased with increasing stand age (O'connell and Menage 1982). Successional shifts in tree species composition may lead to concomitant changes in the chemical and physical characteristics of leaf litter (Montagnini et al. 1993). The relatively higher coefficients of variation (CV) (Table 2) for almost all leaf litterfall nutrient concentration might be attributed to the variability of species composition and density between the sites and season. In conclusion, leaf litterfall nutrient concentration in this study is generally comparable to studies in tropical forests from other regions.

\section{Annual leaf litterfall associated $\mathrm{C}$ and $\mathrm{N}$ fluxes}

The annual leaf litterfall associated $\mathrm{C}$ and $\mathrm{N}$ input in this study ranged from 412 (grazing land) to $1025 \mathrm{~kg} \mathrm{ha}^{-1}$ (old exclosure) and 27 (middle age exclosure) to $68 \mathrm{~kg} \mathrm{ha}^{-1}$ (old exclosure), respectively (Table 3). Annual leaf litterfall $\mathrm{C}$ input in the young and middle age exclosure and

Table 3 Annual leaf litterfall dry matter production and associated $\mathbf{C}$ and $\mathbf{N}$ fluxes at exclosures and grazing land in Kewet district, central dry lowland of Ethiopia

\begin{tabular}{|c|c|c|c|}
\hline Land Use/Factor & LF DM $\left(\mathrm{kg} \mathrm{ha}^{-1}\right)$ & $C\left(\mathrm{~kg} \mathrm{ha}^{-1}\right)$ & $N\left(\mathrm{~kg} \mathrm{ha}^{-1}\right)$ \\
\hline Grazing land & 1073.00 & 412.03 & 27.58 \\
\hline Young exclosure & 1540.90 & 619.75 & 55.16 \\
\hline Middle exclosure & 1628.20 & 621.97 & 32.89 \\
\hline Old exclosure & 2662.40 & 1025.02 & 68.42 \\
\hline
\end{tabular}

old exclosure increased by $50 \%$ and $148 \%$, respectively as compared to the grazing land. Similarly, compared to grazing land, annual leaf litterfall $\mathrm{N}$ input has increased by onefold and $19 \%$ in the young and middle age exclosures, respectively. The old exclosure showed a $148 \%$ increase in $\mathrm{N}$ annual input from the grazing land. Comparing with exclosures, the grazing land had low annual leaf litterfall and associated $\mathrm{C}$ and $\mathrm{N}$ input. Generally, the pattern of annual $\mathrm{C}$ and $\mathrm{N}$ input through leaf litterfall mirrored that of annual leaf litterfall production.

Even though the annual leaf litterfall in this study showed an increase with age of the exclosure, annual inputs of leaf litter $\mathrm{C}$ and $\mathrm{N}$ in all the exclosure were low when compared with that reported for other tropical forests. In moist tropical lowland forests, the annual litterfall ranges between 5000 and $14,000 \mathrm{~kg} \mathrm{ha}^{-1}$ (Osman 2013). Paudel et al. (2015) also observed an annual return of over $3100 \mathrm{~kg}$ of $\mathrm{C} \mathrm{ha}{ }^{-1}$ year $^{-1}$ through leaves litter in the mixed and regenerated tropical montane forest in the southwest of China. They also reported a higher annual addition of $\mathrm{N}$ (100 and $94.74 \mathrm{~N} \mathrm{~kg} \mathrm{ha}^{-1}$ year $^{-1}$ ) through leaves litter in regenerated and mixed tropical montane forest. In a natural forest in Gambo District, southern Ethiopia, the annual return of $\mathrm{C}$ and $\mathrm{N}$ through leaf litterfall was about 5771 and $227 \mathrm{~kg} \mathrm{ha}^{-1}$ year $^{-1}$, respectively.

The low annual leaf litter $\mathrm{C}$ and $\mathrm{N}$ input in all the exclosures and adjacent grazing land compared with other tropical lowland forests could be due to less density and composition of perennial vegetation compared to matured forests. Exclosure is a passive restoration mechanism of degraded landscapes that promotes natural succession processes with native plants (León and Osorio 2014). Exclosure should pass a sequence of a succession process to reach the vegetation density and composition stage of other mature tropical forest ecosystem located in similar climate type. Moreover, mature forest areas are richer in climax species (Descheemaeker et al. 2006) and considered as being in a steady-state. A review by Paudel et al. (2015) has shown differences in nutrient concentration among forests with different plant composition, successional age, and intensity of disturbance. Seta et al. (2017) reported 1177 and $869 \mathrm{~kg}$ of $\mathrm{C} \mathrm{ha}^{-1}$ year $^{-1}$ from leaf litterfall in slightly and highly disturbed Acacia spp. dominated moist evergreen montane forest in the southwestern part of Ethiopia. They also obtained 149 and $127 \mathrm{~kg}$ of $\mathrm{N} \mathrm{ha}^{-1}$ year $^{-1}$ from leaf litterfall, which is higher than the finding of this study.

Annual leaf litterfall $\mathrm{C}$ and $\mathrm{N}$ input exhibited a pronounced increase with increasing age of exclosure. Similar increases of annual litterfall with stand age were reported in dry forest ecosystems of southwestern Australia (O'connell and Menage 1982). Singh et al. (2004) also found an increased amount of litterfall $\mathrm{N}$ with 
Albizia lebbeck plantation age in a dry tropical region in India. The increase of annual leaf litterfall $\mathrm{C}$ and $\mathrm{N}$ input with age of exclosure could be due to increases of above-ground biomass with age. Despite the difference with other tropical forests, the increase of annual leaf litterfall $\mathrm{C}$ and $\mathrm{N}$ inputs with the increase in age of exclosure indicates that self-nourishment is increasing with age of exclosure. Litterfall input is the most important nutrient source, particularly for $\mathrm{C}$ and $\mathrm{N}$ in forest ecosystems. Increases in aboveground litterfall will increase the input of $C$ substrates to the forest floor (Finzi et al. 2001). Nitrogen inputs to the forest floor derive largely from litterfall (Parker 1983). These results suggest that litter is a major process responsible for soil organic matter and nutrient enrichment beneath isolated trees in semi-arid savannas (Mlambo and Nyathi 2008).

As litterfall represents a major nutrient flux from forest to forest soil, changes in aboveground litter production can directly impact the belowground processes (Tian et al. 2010) and are likely to affect soil $\mathrm{C}$ and $\mathrm{N}$ dynamics (Sayer et al. 2007). In Wisconsin, USA, an experiment conducted by Liu et al. (2009) for aspen stand showed a significant influence of soil $\mathrm{C}$ and $\mathrm{N}$ cycles litter production changes. Gautam and Mandal (2018) have also reported almost 1.5 times greater total nutrient return to the soil through the litterfall than that from fine roots in both forests from a tropical moist forest of eastern Nepal. Variation in litterfall and decomposition contributes to differences in the $C$ cycle (Paudel et al. 2015) and the difference between litterfall input and decomposition results in high stock of soil $\mathrm{C}$ and $\mathrm{N}$ (Liski et al. 2002). In conclusion, various types of land degradation had an adverse effect on nutrient stocks (Gautam and Mandal 2018).

\section{Conclusions}

Litter production and organic matter accumulation following vegetation restoration using exclosure can be considered as the most important source of soil organic matter and thus, influencing nutrient cycling processes positively. This study examined leaf litterfall production and associated nutrient fluxes along age of exclosure and adjacent grazing land. Relatively, in all exclosures, higher leaf litterfall input was recorded in the dry months and leaf litterfall production displayed a strong seasonal variation. Mean monthly leaf litterfall production showed a difference between the age of exclosures and adjacent grazing land. This study revealed that an increase in exclosure age will positively affect litterfall input. Annual leaf litterfall $\mathrm{C}$ and $\mathrm{N}$ input exhibited a pronounced increase with increasing age of exclosure and the pattern of annual $\mathrm{C}$ and $\mathrm{N}$ input through leaf litterfall mirrored that of annual leaf litterfall. Therefore, this study states that it will require a longer time to see substantial changes in the leaf litterfall production and associated $\mathrm{C}$ and $\mathrm{N}$ of degraded lands due to exclosures. To determine individual tree species capacity of restoration and recommend appropriate species, further research on the contribution of dominant tree species in litterfall production and their nutrient content along age of exclosure is suggested.

\section{Abbreviations \\ $\mathrm{CO}_{2}$ : Carbon dioxide; SOC: Soil organic carbon; SOM: Soil organic matter.}

\section{Acknowledgements}

The Federal Ministry of Education of Ethiopia is duly acknowledged for financing the research work through Debre Birhan University and for sponsoring Mr. Fikrey Tesfay to pursue his Ph.D. study at Haramaya University, Ethiopia.

\section{Authors' contributions}

FT: Conceived and designed the experiments; performed the experiments; analyzed and interpreted the data; contributed materials, analysis tools or data; wrote the first draft. KK: Designed the experiments; analyzed and interpreted the data; contributed, materials, analysis tools, or data; significantly supported in writing the manuscript and editing. AG: Analyzed and interpreted the data; significantly supported in writing the manuscript and editing. $\mathrm{KMH}$ : Contributed materials, analysis tools, or data; edit the manuscript. All authors read and approved the final manuscript.

\section{Funding}

This research was financed by the Federal Ministry of Education of Ethiopia through Debre Birhan University, Ethiopia.

\section{Availability of data and materials}

Not applicable.

Ethics approval and consent to participate Not applicable.

\section{Consent for publication}

Not applicable.

Competing interests

The authors declare no conflict of interest.

\section{Author details \\ ${ }^{1}$ School of Natural Resources Management and Environmental Sciences, Haramaya University, P.O.Box 138, Dire Dawa, Ethiopia. ${ }^{2}$ College of Agriculture and Natural Resource Sciences, Debre Birhan University, P.O.Box 445, Debre Birhan, Ethiopia. ${ }^{3}$ World Agroforestry Centre (ICRAF), United Nations Avenue, P.O. Box 30677-00100, Nairobi, Kenya. ${ }^{4}$ World Agroforestry Centre (ICRAF), ILRI Campus, P.O. Box 5689, Addis Ababa, Ethiopia.}

Received: 23 January 2020 Accepted: 20 May 2020

Published online: 26 May 2020

\section{References \\ Anderson JM, Ingram JS (eds) (1993) Tropical soil biology and fertility: a hand- book of methods, 2nd edn. CAB Internationa, Wallingford Oxon, UK Attignon SE, Weibel D, Lachat T et al (2004) Leaf litter breakdown in natural and plantation forests of the Lama forest reserve in Benin. Appl Soil Ecol 27:109-124. https://doi.org/10.1016/j.apsoil.2004.05.003 \\ Barlow J, Gardner TA, Ferreira LV, Peres CA (2007) Litterfall and decomposition in primary, secondary and plantation forests in the Brazilian Amazon. For Ecol Manage 247:91-97. https://doi.org/10.1016/j.foreco.2007.04.017 \\ Becker J, Pabst H, Mnyonga J, Kuzyakov Y (2015) Annual litterfall dynamics and nutrient deposition depending on elevation and land use at Mt}


Kilimanjaro. Biogeosci Discuss 12:10031-10057. https://doi.org/10.5194/ bgd-12-10031-2015

Bremner JM, Mulvaney CS (1982) Nitrogen-total. In: Page AL, Miller RH, Keeney DR (eds) Methods of soil analysis, part 2 chemical and microbiological properties, 2nd edn. Madison, ASA, SSSA, pp 595-624

Buh Rquez A, Martmh Nez-Yrmh A, Nu Ez S (1999) Sonoran Desert productivity and the effect of trap size on litterfall estimates in dryland vegetation. J Arid Environ 43:459-465. https://doi.org/10.1006/jare.1999.0547

Celentano D, Zahawi RA, Finegan B et al (2011) Litterfall dynamics under different tropical forest restoration strategies in Costa Rica. Biotropica 43:279-287. https://doi.org/10.1111/j.1744-7429.2010.00688.x

Chenu C, Angers DA, Barré P et al (2019) Increasing organic stocks in agricultural soils: knowledge gaps and potential innovations. Soil Tillage Res 188:41-52. https://doi.org/10.1016/j.still.2018.04.011

Cotrufo MF, De Angelis P, Polle A (2005) Leaf litter production and decomposition in a poplar short-rotation coppice exposed to free-air $\mathrm{CO}_{2}$ enrichment (POPFACE). Glob Chang Biol 11:971-982. https://doi.org/10.111 1/j.1365-2486.2005.00958.x

Dawoe EK, Isaac ME, Quashie-Sam J (2010) Litterfall and litter nutrient dynamics under cocoa ecosystems in lowland humid Ghana. Plant Soil 330:55-64. https://doi.org/10.1007/s11104-009-0173-0

Demessie A, Singh BR, Lal R, Strand LT (2012) Leaf litterfall and litter decomposition under Eucalyptus and coniferous plantations in Gambo District, southern Ethiopia. Acta Agric Scand Sect B Soil Plant Sci 62:467-476. https://doi.org/10.1080/09064710.2011.645497

Descheemaeker K, Muys B, Nyssen J et al (2006) Litter production and organic matter accumulation in exclosures of the Tigray highlands, Ethiopia. For Ecol Manage 233:21-35. https://doi.org/10.1016/j.foreco.2006.05.061

Facelli JM, Pickett STA (1991) Plant litter: its dynamics and effects on plant community structure. Bot Rev 57:1-32. https://doi.org/10.1007/BF028 58763

FAO (2010) Agricultural based livelihood systems in drylands in the context of climate change. Food and Agriculture Organization of the United Nations, Rome, Italy

Finzi AC, Allen AS, Delucia EH et al (2001) Forest litter production, chemistry, and decomposition following 2 years of free-air $\mathrm{CO}_{2}$ enrichment. Ecology 82:470-484. https://doi.org/10.1371/journal.pone.0001299

Gautam TP, Mandal TN (2018) Storage and flux of nutrients in disturbed and undisturbed tropical moist forest of Eastern Nepal. Int J For Res 2018:1-12. https://doi.org/10.1155/2018/8516321

George SJ, Kelly RN, Greenwood PF, Tibbett M (2010) Soil carbon and litter development along a reconstructed biodiverse forest chronosequence of South-Western Australia. Biogeochemistry 101:197-209. https://doi. org/10.1007/s10533-010-9519-1

Gower ST, Son Y (2010) Differences in soil and leaf litterfall nitrogen dynamics for five forest plantations. Soil Sci Soc Am J 56:1959. https://doi. org/10.2136/sssaj1992.03615995005600060051x

Hartmann DL (2016) Atmospheric General Circulation and Climate. In: Hartmann DL (ed) Global Physical Climatology, 2nd edn. Elsevier Inc., Amsterdam, pp 159-193

Hu X, Li X-Y, Wang P et al (2019) Influence of exclosure on CT-measured soil macropores and root architecture in a shrub-encroached grassland in northern China. Soil Tillage Res 187:21-30. https://doi.org/10.1016/j.still .2018.10.020

Hurni H (1998) Agroecological belts of Ethiopia: Explanatory notes on three maps at a scale of 1:1,000,000. Soil Conservation Research Programme. Centre for Development and Environment, Bern

Kim C, Jeong J, Cho HS, Son Y (2010) Carbon and nitrogen status of litterfall, litter decomposition and soil in even-aged larch, red pine, and rigitaeda pine plantations. J Plant Res 123:403-409. https://doi.org/10.1007/s1026 5-010-0317-6

Lemma B, Nilsson I, Kleja DB et al (2007) Decomposition and substrate quality of leaf litters and fine roots from three exotic plantations and native forest in the southwestern highlands of Ethiopia. Soil Biol Biochem 39:23172328. https://doi.org/10.1016/j.soilbio.2007.03.032

León JD, Osorio NW (2014) Role of litter turnover in soil quality in tropical degraded lands of colombia. Sci World J 2014:1-11. https://doi. org/10.1155/2014/693981

Lindsay EA, French K (2005) Litterfall and nitrogen cycling following invasion by Chrysanthemoides monilifera ssp. rotundata in coastal Australia. J Appl Ecol 42:556-566. https://doi.org/10.1111/j.1365-2664.2005.01036.x
Lisanework N, Michelsen A (1994) Litterfall and nutrient release by decomposition in three plantations compared with a natural forest in the Ethiopian highland. For Ecol Manage 65:149-164. https://doi. org/10.1016/0378-1127(94)90166-X

Liski J, Perruchoud D, Karjalainen T (2002) Increasing carbon stocks in the forest soils of western Europe. For Ecol Manage 169:159-175. https:// doi.org/10.1016/S0378-1127(02)00306-7

Liu L, King JS, Booker FL et al (2009) Enhanced litter input rather than changes in litter chemistry drive soil carbon and nitrogen cycles under elevated $\mathrm{CO}_{2}$ : a microcosm study. Glob Chang Biol 15:441-453. https:// doi.org/10.1111/j.1365-2486.2008.01747.x

Loumeto JJ (2003) Litterfall and nutrient return in tropical rainforest in the Chaillu area (southwest Congo). Adv Ecol Sci 19:1237-1249. https://doi. org/10.2495/ECO030462

Lv GH, Zhou GS, Wang XY (2013) Factors controlling litterfall production of forest in China. Adv Mater Res 726-731:4248-4251. https://doi. org/10.4028/www.scientific.net/amr.726-731.4248

Martinez-yrizar A, Sarukhan J (1990) Litterfall patterns in a tropical deciduous forest in Mexico over a 5-year period. J Trop Ecol 6:433-444. https ://doi.org/10.1017/S0266467400004831

Mehta N, Dinakaran J, Patel S et al (2013) Changes in litter decomposition and soil organic carbon in a reforested tropical deciduous cover (India). Ecol Res 28:239-248. https://doi.org/10.1007/s11284-012-1011-z

Mekuria W, Veldkamp E, Haile M et al (2007) Effectiveness of exclosures to restore degraded soils as a result of overgrazing in Tigray, Ethiopia. J Arid Environ 69:270-284. https://doi.org/10.1016/j.jaridenv.2006.10.009

Mlambo D, Nyathi P (2008) Litterfall and nutrient return in a semi-arid southern African savannawoodland dominated by Colophospermum mopane. Plant Ecol 196:101-110. https://doi.org/10.1007/s11258-007-9337-2

Montagnini F, Ramstad K, Sancho F (1993) Litterfall, litter decomposition and the use of mulch of four indigenous tree species in the Atlantic lowlands of Costa Rica. Agrofor Syst 23:39-61. https://doi.org/10.1007/ BF00704850

Motsara MR, Roy RN (2008) Guide to laboratory establishment for plant nutrient analysis. FAO, Rome

Negash M, Starr M (2013) Litterfall production and associated carbon and nitrogen fluxes of seven woody species grown in indigenous agroforestry systems in the south-eastern Rift Valley escarpment of Ethiopia. Nutr Cycl Agroecosyst 97:29-41. https://doi.org/10.1007/ s10705-013-9590-9

Nordén U (1994) Leaf litterfall concentrations and fluxes of elements in deciduous tree species. Scand J For Res 9:9-16. https://doi.org/10.1080/02827 589409382807

O'connell AM, Menage PMA (1982) Litterfall and nutrient cycling in karri (Eucalyptus diversicolor F. Muell.) forest in relation to stand age. Aust J Ecol 7:49-62. https://doi.org/10.1111/j.1442-9993.1982.tb01299.x

Osman KT (2013) Forest soils: properties and management. Springer International Publishing, Switzerland

Özcan M, Gökbulak F, Hizal A (2013) Exclosure effects on recovery of selected soil properties in a mixed broadleaf forest recreation site. L Degrad Dev 24:266-276. https://doi.org/10.1002/ldr.1123

Oziegbe MB, Muoghalu JI, Oke SO (2011) Litterfall, precipitation and nutrient fluxes in a secondary lowland rain forest in lle-lfe, Nigeria. Acta Bot Brasilica 25:664-671. https://doi.org/10.1590/s0102-33062011000300020

Parker GG (1983) Throughfall and stemflow in the forest nutrient cycle. Adv Ecol Res 13:57-133. https://doi.org/10.1016/S0065-2504(08)60108-7

Paudel E, Dossa GGO, Xu J, Harrison RD (2015) Litterfall and nutrient return along a disturbance gradient in a tropical montane forest. For Ecol Manage 353:97-106. https://doi.org/10.1016/j.foreco.2015.05.028

Proctor J, Anderson JM, Fogden SCL, Vallack HW (1983) Ecological studies in four contrasting lowland rain forests in Gunung Mulu National Park, sarawak: II. Litterfall, litter standing crop and preliminary observations on herbivory. J Ecol. 71:261. https://doi.org/10.2307/2259976

Rai A, Singh AK, Ghosal N, Singh N (2016) Understanding the effectiveness of litter from tropical dry forests for the restoration of degraded lands. Ecol Eng 93:76-81. https://doi.org/10.1016/j.ecoleng.2016.05.014

Rogers HM (2002) Litterfall, decomposition and nutrient release in a lowland tropical rain forest, Morobe Province, Papua New Guinea. J Trop Ecol 18:449-456. https://doi.org/10.1017/\$0266467402002304

Ryan Mg, Law BE (2005) Interpreting, measuring, and modeling soil respiration. Biogeochemistry 73:3-27. https://doi.org/10.1007/s10533-004-5167-7 
Sayer EJ, Tanner EVJ (2010) Experimental investigation of the importance of litterfall in lowland semi-evergreen tropical forest nutrient cycling. J Ecol 98:1052-1062. https://doi.org/10.1111/j.1365-2745.2010.01680.x

Sayer EJ, Powers JS, Tanner EVJ (2007) Increased litterfall in tropical forests boosts the transfer of soil $\mathrm{CO}_{2}$ to the atmosphere. PLOS ONE 2:1-6. https ://doi.org/10.1371/journal.pone.0001299

Schulte A, Ruhiyat D (eds) (2013) Soils of tropical forest ecosystems: characteristics, ecology, and management. Springer-Verlag, Berlin Heidelberg

Seta T, Demissew S, Woldu Z, Lemenih M (2017) Carbon and nutrient release patterns during leaf litter decomposition in Boter-Becho forest, Southwestern Ethiopia. J Ecosyst Ecography 06:1-9. https://doi. org/10.4172/2157-7625.1000222

Shen Z, Sun Q, Liu M (2014) Soil carbon and nitrogen dynamics induced by tissue-litter decomposition of copper mine tailings from the Gramineae and cryptogram communities, China. Anal Lett 47:885-899. https://doi. org/10.1080/00032719.2013.853181

Singh AN, Raghubanshi AS, Singh JS (2004) Comparative performance and restoration potential of two Albizia species planted on mine spoil in a dry tropical region, India. Ecol Eng 22:123-140. https://doi.org/10.1016/j. ecoleng.2004.04.001

Talemos S, Sebsebe D, Zerihun W (2018) Litterfall dynamics in boter-becho forest: moist evergreen montane forest of Southwestern Ethiopia. J Ecol Nat Environ 10:13-21. https://doi.org/10.5897/jene2017.0648

Tam NFY, Wong YS, Lan CY, Wang LN (1998) Litter production and decomposition in a subtropical mangrove swamp receiving wastewater. J Exp Mar Bio Ecol 226:1-18. https://doi.org/10.1016/S0022-0981(97)00233-5

Tang JW, Cao M, Zhang JH, Li MH (2010) Litterfall production, decomposition, and nutrient use efficiency varies with tropical forest types in Xishuangbanna, SW China: a 10-year study. Plant Soil 335:271-288. https://doi. org/10.1007/s11104-010-0414-2

Tang J, Davy AJ, Jiang D et al (2016) Effects of excluding grazing on the vegetation and soils of degraded sparse-elm grassland in the Horqin Sandy Land, China. Agric Ecosyst Environ 235:340-348. https://doi.org/10.1016/j. agee.2016.11.005

Tefera M, Chernet T, Haro W (1996) Geological map of Ethiopia: topographic base map, scale 1:2,000,000, 2nd edn. Geological Survey of Ethiopia, Addis Abeba
Teketay D, Kashe K, Madome J et al (2018) Enhancement of diversity, stand structure and regeneration of woody species through area exclosure: the case of a mopane woodland in northern Botswana. Ecol Process 7:1-15. https://doi.org/10.1186/s13717-018-0116-x

Tian DL, PENG YY, YAN De W et al (2010) Effects of thinning and litter fall removal on fine root production and soil organic carbon content in masson pine plantations. Pedosphere 20:486-493. https://doi.org/10.1016/ S1002-0160(10)60038-0

Tonin AM, Gonçalves JF, Bambi P et al (2017) Plant litter dynamics in the foreststream interface: precipitation is a major control across tropical biomes. Sci Rep 7:1-14. https://doi.org/10.1038/s41598-017-10576-8

Uriarte M, Turner BL, Thompson J, Zimmerman JK (2015) Linking spatial patterns of leaf litterfall and soil nutrients in a tropical forest: a neighborhood approach. Ecol Appl 25:2022-2034. https://doi.org/10.1890/15-0112.1

Vitousek PM (1984) Litterfall, nutrient cycling, and nutrient limitation in tropical forests. Ecology 65:285-298. https://doi.org/10.2307/1939481

Vogt KA, Grier CC, Vogt DJ (1986) Production, turnover, and nutrient dynamics of above- and belowground detritus of world forests. Adv Ecol Res 15:303-377. https://doi.org/10.1016/S0065-2504(08)60122-1

Williams FM (2016) Understanding Ethiopia: geology and scenery. Springer International Publishing, Basel

Zhang M, Schaefer DA, Chan OC, Zou X (2013) Decomposition differences of labile carbon from litter to soil in a tropical rain forest and rubber plantation of Xishuangbanna, southwest China. Eur J Soil Biol 55:55-61. https:// doi.org/10.1016/j.ejsobi.2012.12.003

Zhao J, Chen S, Hu R, Li Y (2017) Aggregate stability and size distribution of red soils under different land uses integrally regulated by soil organic matter, and iron and aluminum oxides. Soil Tillage Res 167:73-79. https://doi. org/10.1016/j.still.2016.11.007

\section{Publisher's Note}

Springer Nature remains neutral with regard to jurisdictional claims in published maps and institutional affiliations.

\section{Submit your manuscript to a SpringerOpen ${ }^{\circ}$ journal and benefit from:}

- Convenient online submission

- Rigorous peer review

- Open access: articles freely available online

- High visibility within the field

- Retaining the copyright to your article

Submit your next manuscript at $\boldsymbol{\nabla}$ springeropen.com 